\title{
THE AUTONOMISATION OF THE CULTURAL FIELD IN LATE SOCIALIST ALBANIA AND THE EMERGENCE OF EARLY SOCIOLOGICAL RESEARCH
}

\author{
Sokol Lleshi \\ European University of Tirana \\ Teuta Starova \\ University of Tirana
}

\section{/// Introduction}

Most East-Central European countries had a pre-war tradition of sociology either centred on a particular school of social research, as in Poland or Romania (Bosomitu 2017; Szacki 1998), or instrumental to public discourses of modernisation enunciated by intellectuals. Notwithstanding acquaintance with outstanding figures in sociology such as Durkheim, Simmel, or Spencer, the pre-war intellectuals in Albania - most prominently Branko Merxhani - were grappling with processes of nation building and societal transformation; they treated sociology loosely and normatively, as if it provided an ideological blueprint (Sulstarova 2007: 82; Ypi 2007: 673). Consequently, Albania did not share a similar tradition of pre-war sociology with other state socialist countries of East-Central Europe. The aim of this paper is to situate Albania's unique experience of the emergence of sociology under the state socialist regime within the broader regional experience of the emergence (or re-emergence) and institutionalisation of sociology (Vorríšek 2008) and to explain the particularity of the Albanian case.

In explaining the trajectory of social science, and specifically of sociology under socialism, there is a shared recognition in the literature of the pivotal role played by the de-Stalinisation process, which resulted in a more liberalised cultural policy and provided relative autonomy for the social 
sciences (Beliaev \& Burtorin 1982: 421; Shalin 1978: 173; Vořríšek 2008: 91). However, ample and sometimes contradictory explanations are given for the other causes of the emergence and institutionalisation of sociology. Some authors consider that sociology emerged as a result of the state socialist regime's inefficacy in addressing the pressing problems of industrialisation; the solutions were then supposed to be found in "concrete social research" or in the sociological discipline (Beliaev \& Burtorin 1982: 431; Lane 1970: 48). Other authors consider the establishment of sociology to have been the result of a bottom-up process triggered by a local sociological movement, or international influence (Shalin 1978: 174). The literature seems rather inconclusive on the role of other explanatory factors for the establishment and institutionalisation of sociology across state socialist Europe and in the Soviet Union.

This paper addresses the following research question: what shaped the emergence of sociological research during the period of late socialism in Albania? The second aim of the paper is to reveal the causal mechanism by which a liberalised cultural policy brought about a shift. The traditional role of the socialist intelligentsia lessened in importance while the role of social scientists emerged; in the very final years of the state socialist regime, in 1989 to 1990, these latter were pitted against Party cadres and representatives in defending a limited yet free academic practice. In order to explain the intricate process of the emergence of sociology under state socialism in Albania, this paper utilises a layered theoretical framework that tries to capture the interaction between stages of regime development (Jowitt 1992), the co-existence of various competing modes of legitimation (Verdery 1991), and the transformation of the heteronomous sector of cultural production into an emergent field of cultural production (Bourdieu 1992). As Voř́ršek (2008) mentions when explaining the various patterns of sociology's institutionalisation as a discipline across Soviet Europe, the emergence of sociology under state socialist regimes mostly involved the scientific field's being configured in spite of frequent regime controls and restrictions. In Albania, this particular process took place after regime change. However, the trajectory of sociology's emergence during the late period of the state socialist regime affected the discipline's post-1989 institutionalisation. In most of the countries of socialist East-Central Europe a different theoretical perspective than the one proposed here for Albania is prompted by the presence of institutionalised international contacts or membership in an international network of sociologists, the establishment of national sociological associations, and the institutionalisation of sociol- 
ogy as a discipline, with the establishment of sociology departments under various labels.

\section{/// The Theoretical Framework}

The sociologists in state socialist Albania were not involved in a struggle with the regime for defence of the discipline because of their interstitial position as the ideological intelligentsia (Szelényi 1982: S311) within the field of power and as cultural producers in the quasi-autonomous emerging cultural field. A distinction should be made here between the Bourdieusian notion of the "field" and the notion of a "heteronomous sector." During a large part of the existence of the state socialist regime in Albania there were cultural producers - writers, artists, professors of philosophy, historians, and art critics - but not a field of cultural production. The degree of a field's autonomy is the main component of the concept (Bourdieu 1992: 220). Such a degree of autonomy is defined as "negative sanctions inflicted on heteronomous practices such as direct subjugation to political directives $[\ldots]$ and especially by the strength of the positive incitements to resistance and even to open struggle against those in power" (Bourdieu 1992: 221). During the Stalinist period of Albania's state socialist regime, the cultural production was, as Verdery claims, "a minor category of ideological activism" (1991: 88). Henceforth, it is better to use the term "heteronomous sector" (Bourdieu 1992: 259) than the notion of a "politicized cultural field" (Verdery 1991: 116). The notion of sector exemplifies the cultural sector or the scientific sector during the Stalinist period.

Juxtaposing the period from the late 1950s to the late 1970s with the period of the mid-1980s to 1990 clarifies the transformation of the state socialist regime in Albania and the transformed position of the socialist intelligentsia involved in the cultural sector vis-à-vis the regime. This paper uses Jowitt's theory of the stages of Leninist regimes (1992) in order to assess the conditions that trigger the variegated relation between society and the Party-state. An alternative theory, which in this case has less applicability, is the theory of the ascendancy of the intelligentsia to class power (Konrád \& Szelényi 1979). An important initial condition - which is not fulfilled in the Albanian case - for the rise of the intelligentsia as agents of the "rationalisation of the system of legitimation" (Szelényi \& Martin 1988: 664), is the "relative separation of the economy from the political" (Szelényi 1982: 311). The Albanian state socialist regime did not permit the emergence of a technocratic intelligentsia that would have been crucial in 
the engineering of market socialism reforms. However, a process of "opening up [the party bureaucracy] ranks to the intelligentsia" (Szelényi \& Martin 1988: 665) did happen in the late 1980s. Indeed, such an event entailed a simultaneous process whereby the transformation of the cultural sector into an emerging cultural field encouraged the early formation of sociology and the reconfiguration of the field of power, in which cultural capital started to dominate over political capital. Actually, the ascendancy of the cultural intelligentsia in Albania is a result of the congruence between the crisis of Marxist-Leninist ideological legitimation and the regime's reformist cycle, whose inclusive dimension had unintended consequences. The after-effects of this process were that a portion of the cultural intelligentsia ascended to power in the post-socialist regime and that sociology was consolidated as a discipline.

The transformative stage of the state socialist regime in Albania, which aimed to "alter or destroy values, structures [...] contributing to the actual or potential existence of alternative centers of power" (Jowitt 1992: 56), lasted from the immediate post-Second World War period up to the late 1950s. The main transformative goals of the regime were to weaken the merchant class, representatives of the national bourgeoisie, public intellectuals, and patriarchal relations in rural areas. The coercive mode of legitimation was rather dominant during this period. Henceforth, the confrontation was between "unreconstructed society" and the communist party apparatus (Jowitt 1992: 57). At this stage, the state socialist regime had not yet managed to make the education of the socialist intelligentsia local. The consolidation phase of the regime, which included the period between 1960 and 1979, had intermittent cycles of aborted liberalising reforms; it created interaction between the socialist intelligentsia and the regime based on "ideological-political orientation" (Jowitt 1992: 74) and adherence to the party line. The role of cultural producers in the cultural and educational sector was to enhance Party propaganda and the ideological education of society. At this stage the dominant capital in the field of power was political capital. No clear distinction was made between experts with a "formal role prescription" (Jowitt 1992: 74) and the "politically relevant behaviour" (ibid.) of the party cadres. The socialist intelligentsia at this period can be considered "task-achieving cultural producers" dependent on Party directives.

The weakening of Marxist-Leninist ideology in the 1980s, and the discontinuity of dependency on a socialist hegemonic power such as the Soviet Union or China, made the state socialist regime open its ranks in

\section{/ 122 STANRZECZY [STATEOFAFFAIRS] 2[13]/2017}


the administrative apparatus and economic sector to non-party members of the socialist intelligentsia. The "more professional, skilled and articulate strata" (Jowitt 1992: 95) started to replace the party bureaucracy. This professional strata articulated policy formulations on the social problems of the post-consolidation - if not modernisation - phase, by providing novel "ideological definitions" (Jowitt 1992: 92). It is at this juncture that the regime aimed to "enhance its legitimacy without sacrificing the charismatic exclusiveness of its apparatchik component" (Jowitt 1992: 93). A more relaxed cultural policy on the socialist intelligentsia involved in the cultural-educational sector emerged. The notion of the co-existence of various principles of legitimation (Rigby 1982: 15) is utilised to indicate the symbolic-ideological legitimation (Verdery 1991) of the Albanian socialist regime, based on national ideology as well as Marxist-Leninist ideology. As the article shows, legitimation based on national ideology was less efficient in the mid-1980s, or at least it was a smokescreen. It was not the historians and ethnologists but the ideological intelligentsia - the sociologists and professors of political economy - who proposed policy reforms to solve the social problems facing the regime.

Apart from the regime-level analysis, the present paper explains the causal process of the emergence of the cultural field and the interstitial position of the emerging cultural intelligentsia based on the Bourdieusian framework. This conceptual toolkit is utilised in conjunction with the theorisation of the expert community, which was characterised by collegiality, occupational closure, and non-political value commitments (Waters 1989: 946). The post-consolidation phase of the state socialist regime engendered the reconfiguration of the field of power. This concept is defined as "the space of relations of force between agents or between institutions having in common the possession of the capital necessary to occupy the dominant positions in the different fields" (Bourdieu 1992: 215). The main institutions involved in the cultural sector included the Institute for Marxist-Leninist Studies, the Academy of Sciences, the V.I. Lenin Party School, and the State University of Tirana. Other state agencies involved included the State Planning Office and the Science Committee of the Prime Minister's Office. In the late 1980s, the influence of the Institute for Marxist-Leninist Studies and the V.I. Lenin Party School waned and the State University of Tirana became the locus for the articulation of the cultural field. Some representatives of defunct institutions were transferred to the State University. The Academy of Sciences played an important role in establishing the institutional infrastructure for the professionalisation of expertise, re- 
gardless of the decline of the national ideology it had helped to establish. Agents possessing cultural capital replaced party bureaucracy in the leading positions of the cultural sector, and economists proposed certain policy reforms for the restructuring of enterprises and economic decentralisation. The process of the autonomisation of the cultural field (Bourdieu 1992: 248) from ideological control implied different value commitments, demands, and strivings for further professionalisation, and the occupation closure of a "pure producer" (ibid.: 257), with its specific position-takings.

\section{/// The Social Sciences and the State Socialist Regime before the} Post-Consolidation Phase

\section{The Dissolution of Expertise: Anyone Can Be a Scientific Worker during the Cultural Revolution}

During the first stage of its rule, the state socialist regime exhibited its transformative goal, which pitted the Party against unreformable society. Official party documents written by the leading party ideologues specify the tasks that the Party organisations and the socialist intelligentsia were supposed to accomplish to reach the transformative goal. Educating the educators - mainly party officials in charge of revolutionising society - was conceived as parallel to the processes of eradicating the remnants of the past regime and social structure: "the revolutionary actions of the communists and workers, and their participation in the battle for progress and destruction of everything archaic, and the building of the new, is a powerful educational tool" (Alia 1969: 18). ${ }^{1}$

In the consolidation phase the regime aimed at the eradication of the cultural practices and "vestiges" of bourgeois society. "We are witnessing a new phase that is characterised by a frontal assault against all the 'blemishes' of the old feudal-bourgeois society in politics, economy, ideology, and culture"(Hoxha 1969: 25). The Party ideology considered party officials and the socialist intelligentsia to be as capable of producing studies as any secluded group of social scientists.

In 1951, the state socialist regime had already initiated a process to produce its own socialist intelligentsia; it established three institutes of higher learning, on the Soviet model, with the intention to "form the intelligentsia of our land" (Rouček 1958: 56). In 1957, the State University was estab-

\footnotetext{
1 All translations of cited fragments are our own.
} 
lished. An early attempt to resuscitate the internal party discussions (on the order of Khrushchev's anti-Stalinist position) that had taken place at the Tirana Party Conference in 1956 was nipped in the bud (Lalaj 2015). One might imagine that the liberalisation of cultural policy followed the initial stage of Marxist revisionism within the Party. By scrutinising official party documents delineating regime policies on the role of cultural producers and the objectives of particular sectors of the social sciences (as presented by their leading representatives), the socialist intelligentsia's subordinate position in regard to the party bureaucracy and its rule becomes clearer.

The source of legitimacy remained Marxist-Leninist doctrine and the knowledge claims of the Party. Nexhmije Hoxha, head of the Institute for Marxist-Leninist Studies, explained at a convention on the role of the social sciences that "the study of social problems cannot be an issue solely for a group of specialists - but an issue of all the party cadres, primarily of the communists and local party secretaries" (1969: 23). The prescribed function of social research on social issues was to enhance the ideological and educative effect rather than to provide applicative social research on various sectors of society or the economy, let alone to trigger theory-based research. "The studies on social issues will contribute to the enhancement of propaganda work and agitation, as well as to educational, cultural, and organisational work"'(Hoxha 1969: 24). At the height of the Maoist revolutionary zeal of the state socialist regime, doing social research became massive and popularised, recognising no hierarchy or previously established authority. Albanian scholars, who were mostly trained historians before the war, were labelled esoteric. Their claim to scholarly authority was challenged and not considered useful. "Before, we wrongly considered that only 'specialists' or 'historians,' who were trained as such, could study social issues. We had little faith in the large masses of workers, farmers, intelligentsia, social activists, and officers to accomplish this task" (Hoxha 1969: 24).

To wit, during the first decades of the state socialist regime, the cultural producers did not conduct their studies within an autonomous cultural field. Conformity to the directives of the Party was manifested even in self-criticism employed by the members of this heteronomous cultural sector when presenting their role. Science was within the grasp of any member of the socialist intelligentsia or party bureaucracy, or of a worker, and henceforth was not the mark of a particular profession, or symbolic capital. Most members of the academia with positions in higher learning institutes 
or at the Institute of Marxist-Leninist Studies were linguists, ethnologists, political economists, or historians.

There was a certain hierarchy within the ideological intelligentsia that was based on proximity to the Party and shown by being in charge of various ideological tasks within the cultural sector, such as taking part in state committees, or proposing the long-term goals of a particular field of work. Kostallari was one of the leading members of the ideological intelligentsia in the sector of linguistics, head of the Institute of History and Linguistics, and dean of the Faculty of History and Philology for quite some time. Studies were conceived to help "party committees and mass organisations to enhance the ideological work of the party organisations" (Kostallari 1969: 128). On the other hand, party members and workers were considered to be as capable of conducting studies as members of scholarly institutes. "The solution [...] requires the massification of studies directed by party committees in every region and every county" (Kostallari 1969: 129). In the economic sphere, the state socialist regime intended to introduce the direct participation of workers in managing production (Mara 1969: 105). Those that possessed expertise or were responsible for economic planning, such as directors of state enterprises, engineers, or head of units, were labelled bureaucrats. The leading representatives of the scientific sector showed a propensity to propagate "scientifically" the so-called "line of the masses."

At the margins of the scientific sector there were limited attempts to introduce certain innovations in the study of state socialist society. In the late 1960s certain scholars at the Institute of Marxist-Leninist Studies suggested that the "methods" of "bourgeois" sociologists of the West and of "revisionist" sociologists in the socialist camp should be used instrumentally to study public opinion (officially called "social opinion") (Avdia 1969: 177). The use of these methods borrowed from "bourgeois" sociologists was linked to the actual practice of the political mobilisation of the masses and the expansion of workers' control in factories and state enterprises. Although the recognition of certain sociological methods by some members of the Institute for Marxist-Leninist Studies is rather impressive, it was insufficient to bring about the establishment of a sociological research unit within this particular Institute, or for the conduct of applicative social research. There is no marked continuity between the initial, instrumental attempt to introduce sociological methods surreptitiously within a Marxist ideological framework in the late 1960s and the process, in the late 1980s, of substituting sociological research for Marxist-Leninist dogma. More- 
over, the status of the social researchers in the 1960s and 1970s differed from the role and status of the socialist intelligentsia during the inclusive phase of the state socialist regime in the late 1980s.

\section{The Onslaught on State Bureaucracy}

The Leninist type of party considered bureaucracy a hindrance to the participation of the masses in the socialist administration of society (Wright 1974: 85). The main characteristics of bureaucracy, according to Weber, involve "expert and technical knowledge" (1974: 72). Allowing the emergence and consolidation of professional groups within the state bureaucracy constituted a challenge to the monopoly of knowledge and power exercised by the Party apparatus. As Waters explains, the central components of collegial structures among professional groups include structural specialisation, value commitment, and occupation closure (1989: 946). The state socialist regime in Albania devised particular measures to weaken and restrict, if not quell, the occupation closure of the state bureaucracy and technocracy (Çami 1972: 18), claiming that this amounted to undue privilege and distancing from the masses. On the other hand, continuous reshuffling of the state bureaucracy and use of workers' control over the state administration were among the measures that atomised and alienated the bureaucracy, affecting its stability.

During the Cultural Revolution, any professional group that might have emerged among the cultural intelligentsia and technocracy and claiming allegiance to different value commitments than Marxist-Leninist ideology and the Party's "theoretical thinking" would be confronted with the downgrading of their expertise and the inclusion of party representatives, the masses, and workers in the production of knowledge. For quite some time, the state bureaucracy was subordinate to the Party. The prevailing official discourse of the regime delineates bureaucratisation, intellectualism, and technocracy as threats to the dictatorship of the proletariat. Members of the state socialist intelligentsia in leading positions of the educational and cultural sector, such as university deans or department directors, and the heads of party institutes such as the V.I. Lenin Party School and Institute of Marxist-Leninist Studies, were engaged in an ideological battle against the bureaucracy. Luan Omari, dean of the Faculty of Law and Political Sciences at the State University of Tirana praised the Party for subduing the bureaucracy: "Experience of the construction of socialism has proved that the strengthening of the dictatorship of the proletariat $[. .$.$] cannot be$ 
ensured without a resolute struggle against the bureaucracy" (1972: 18). This position of the cultural intelligentsia has been constant through time. In the late 1970s Zija Xholi, dean of the Faculty of Law and Political Sciences, reiterated that bureaucratisation posed a hindrance: "It undermines the links between the state power and the people [...] cultivates conceit in the cadres, such as 'respect' for oneself and scorn for the masses" (1984: 8). The state socialist cultural intelligentsia itself did not yet constitute a professional group that was "self-controlling and self-policing" (Waters 1989: 958) nor did it express different value commitments. However, during the late 1970s to mid-1980s, with the change of leadership of the Party of Labour of Albania (PLA), the state socialist regime started to "mobilise expert knowledge" (Waters 1989: 952) by incorporating members of the cultural intelligentsia, who were engaged in ideological battles and in raising the educational attainments of the socialist intelligentsia, into committees on intellectual-work policies at the behest of the Party-state. The state socialist regime could have chosen a different path of recognising and incorporating its defeated technocratic intelligentsia.

The early 1970s had constituted a brief interlude in which the technocratic intelligentsia, occupying ministerial, state enterprise, and management positions in the state bureaucracy, became ascendant. The weakening of economic cooperation with China conditioned the country's failure "to achieve many of its planned targets in the 1971-1975 plan" (Larrabee 1978: 65). In this context, attempts were made to introduce some degree of economic liberalisation in the centralised socialist economy (Larrabee 1978: 67). Abdyl Këllezi, an economist educated before the war, occupied various positions in the administration of the socialist economy, including chairman of the State Planning Commission (1968-1975), and cooperated with the minister of industry and the minister of trade on a "slight liberalisation of Albania's course" (ibid.). The party apparatus undertook purges in the state bureaucracy, in particular within the "top echelons of the state administration [...] particularly in the economic field" (Larrabee 1978: 68). Short, intermittent cycles of attempted reforms in 1956 and 1972 were followed by long periods of the primacy of the Marxist-Leninist ideology, partinost, and the ascendancy of the party bureaucracy. As in the case of Romania (Verdery 1991: 106), a reform and technocratic constituency was lacking. The emerging constituency of the last short cycle of reforms emerged not within the technocratic intelligentsia but within the ideological intelligentsia engaged in the cultural-educational sector of the state socialist regime. As the next section demonstrates, the regime was invested at the same time 
in a different discourse than the Marxist-Leninist ideology - a discourse characterised, according to Verdery, by "symbolic and ideological appeals to the Nation" (1991: 86). This process had implications for the status and understanding of the social sciences.

\section{The Legitimation Effects of National Ideology and the Reproduction of Expertise}

The Academy of Sciences, which was based on the Soviet model, was established in 1972 and incorporated the various existing scientific institutes. ${ }^{2}$ Historians, linguists, and ethnologists constituted the bulk of its scholars. The social sciences were primarily conceived to pertain to national identity, folklore, national history, and the language of the Albanian people. In one of the official documents presented to the Council of Ministers by representatives of the Academy of Sciences in the late 1970s, the social sciences are defined as "already well-established Albanian national sciences." 3 This particular understanding of the social sciences, with a focus on contemporary history and the so-called socialist construction, did not include sociology. The only reference to sociology in official documents regarding scientific planning was a thematic reference. The official document on "The Broadening and Uplifting of the Quality of Contemporary Historical Studies" mentions important research themes, whose character is "historical, economic, and sociological." Ot Overall, the social research accomplished at the Academy of Sciences became subordinate to national ideology.

By the late 1970s, social research was mainly centred at the Academy of Sciences as a coordinating institution between the State University of Tirana, the Institute of Marxist Leninist Studies, and the V.I. Lenin Party School. The party's official discourse on scientific policy, compared to the

\footnotetext{
${ }^{2}$ It should be noted that after the Second World War, the state socialist regime inherited a research institute named the Institute for Albanian Studies, which was established during the fascist occupation. This structure was later transformed into the Institute of Sciences, maintaining some of the historians and linguists, who had been educated in Western Europe, as members of the refashioned Institute of Sciences. What unites the two academic institutions under these two different regimes is the dominance of Albanology as a defining feature of social science studies.

${ }^{3}$ National State Archives of Albania, Council of Ministers fonds, file 47/1979, p. 3: "Relacion për forcimin e partishmërisë proletare dhe të karakterit kombëtar të studimeve në institucionet e shkencave shoqërore dhe në shkollat e larta" [Report on Strengthening the Proletarian Partinost and the National Character of Studies in Institutions of Social Sciences and of Higher Education]. ${ }^{4}$ National State Archives of Albania, Council of Ministers fonds, file 47/1979, p. 11: "Projektvendim për forcimin e mëtejshëm të partishmërisë proletare dhe të karakterit kombëtar të studimeve në shkencat tona shoqërore" [Draft Law to Further Strengthening the Partinost and the National Character of Our Social Studies].
} 
discourse of the 1960s which treated specialists, Party bureaucrats, and other communists as equal in matters of science, started to provide more official recognition to the expertise and symbolic capital of researchers and academics working in the scientific sector. Nonetheless, ideologically taskoriented social research persisted until it started to wane or be replaced in the mid-1980s.

Contrary to the cases of other state socialist societies, in which "cultural producers," as Verdery calls them, were engaged "in struggles over the nation" (1991: 11) in cooperation or in contradiction to the Party and among themselves, the Albanian case does not display competing discourses on the nation articulated autonomously from the prevailing narrative constructed by the regime. As a consequence, this faction of the cultural intelligentsia took part in legitimating the state socialist regime through national ideology, rather than in challenging the prevailing official narrative on the Albanian nation. To wit, no real "politics of culture" (Verdery 1991: 12) took place that would have pitted various sub-groups of historians and social scientists against each other over discourse on the nation. In a way, to a larger extent, cultural production was subdued to the "category of ideological activism" (Verdery 1991: 88). The discourse on the nation was rather homogenous. This is not to say that members of this faction of the cultural intelligentsia did not attempt to assert the primacy of their expertise over ideological and political demands and thus to manifest their cultural capital. In the late 1970s, when the regime was in its post-consolidation phase, academic historians made their claims on the recognition of expertise and their understanding of "scientific work." A good illustration was the dispute between the president of the Academy of Sciences, Aleks Buda, and Prime Minister Shehu on the primacy of expertise in regard to archaeological expeditions. The regime demanded hasty conclusions and results, whereas the academics showed more restraint, and claimed that "this is first of all an archaeological problem." More than a process of making new, competing knowledge claims it was a process in which cultural producers had their expertise mobilised by the regime to induce ideological effects. This condition did produce a certain friction between social scientists' understanding of expertise and the Party's understanding of the role of science, putting the brakes on ideological zeal. Nonetheless, it did not question the primacy of the Marxist-Leninist dogma.

\footnotetext{
${ }^{5}$ National State Archives of Albania, Council of Ministers fonds, file 47/1979, p. 17: "Procesverbal i mbledhjes së kryesisë së këshillit të ministrave mbi shqyrtimin e relacioneve" [Council of Ministers Meeting Record on Examining Reports].
} 
The usual practice of task-achieving cultural producers required the use of specific genres of cultural production, which can be termed "position-takings." The socialist intelligentsia involved in the cultural sector had to provide generalisations: synthetic conclusions in official reports to the Party, the government, or at scientific events. A certain part of these generalisations and non-empirical theoretical syntheses were dedicated not only to normative "exhortations" (Verdery 1991) in favour of the ideology but to critique of bourgeois and revisionist scholars. Keeping "bourgeoisrevisionist ideological aggression" at bay was one of the tasks. At the same time, in the late 1970 s the state socialist regime intensified diplomatic relations with Western countries such as Italy, Austria, Greece, and France, thus providing exchange and research opportunities for Albanian cultural producers.

In contradiction to the rhetorical demands for the compliance of cultural producers with "ideological-political orientations" (Jowitt 1992), which were manifested in the "political and ideological content" of cultural production, and for cultural producers themselves to have a "sound political, ideological, and scientific Marxist-Leninist education," 8 the regime initiated the professionalisation of social scientists. The Academy of Sciences played a coordinating role in the process of enhancing the expertise of cultural producers. A 1979 internal document of an official meeting of the Academy of Sciences' social section on postgraduate research indicates the disciplinary-based criteria for prospective research: "Dissertation themes should encourage research and bring something new." Propaganda-based research and compilation-type research was not supported. ${ }^{10}$ The regime's recognition of the socialist intelligentsia's expertise stemmed from the Party's attempt to shift from ideological-political compliance to novel ideological definitions, which implied policy proposals to feed "the policy-

\footnotetext{
${ }^{6}$ National State Archives of Albania, Council of Ministers fonds, file 47/1979, p. 40: "Procesverbal i mbledhjes së kryesisë së këshillit të ministrave mbi shqyrtimin e relacioneve" [Council of Ministers Meeting Record on Examining Reports] .

${ }^{7}$ National State Archives of Albania, Council of Ministers fonds, file 47/1979, p. 46: "Procesverbal i mbledhjes së kryesisë së këshillit të ministrave mbi shqyrtimin e relacioneve" [Council of Ministers Meeting Record on Examining Reports].

${ }^{8}$ National State Archives of Albania, Council of Ministers fonds, file 47/1979, p. 45: "Procesverbal i mbledhjes së kryesisë së këshillit të ministrave mbi shqyrtimin e relacioneve" [Council of Ministers Meeting Record on Examining Reports].

${ }^{9}$ National State Archives of Albania, Academy of Sciences fonds, file 19/1979, p. 7: "Tematika për fushat e shkallës së pare të kualifikimit shkencor pasuniversitar në shkencat shoqërore” [Topics for the First Level of Postgraduate Scientific Qualifications in Social Sciences].

${ }^{10}$ National State Archives of Albania, Academy of Sciences fonds, file 19/1979, p. 7: "Tematika për fushat e shkallës së pare të kualifikimit shkencor pasuniversitar në shkencat shoqërore" [Topics for the First Level of Postgraduate Scientific Qualifications in Social Sciences].
} 
making of the Party." 11 This does not mean that the previous practices of the massification of social research were not present as well. The institutional basis for further professionalisation was set by establishing external qualifications through various programmes abroad and the use of "scientific debates, conferences on particular scientific problems and lectures." ${ }^{2}$

\section{/// The Emergence of Sociology, the Autonomisation of the Cultural Field, and the Crisis of Marxist Ideology}

\section{Uncertainties of the Post-Consolidation Phase: Opening the Ranks to the Cultural Intelligentsia}

The Ninth Party Congress of the Party of Labour of Albania, held in November 1986, constituted a turning point in the ideological discourse of the leading heights of the Party-state and in the process of reconfiguring the field of power. Ramiz Alia became the first secretary of the PLA after the death of Enver Hoxha in 1985. The regime's new leadership loosened the ideological restrictions and limited the use of coercion. Although the regime publicly manifested its ideological objection to "revisionist" policies in the Soviet Union and to "the restoration of the bourgeoisie" in EastCentral Europe, in facing the uncertain prospective trajectory of the state socialist regime and the existing immobility of the centralised economy, with the waning of its legitimacy among the working classes and young generation (Biberaj 1998: 30), it initiated a new reform cycle. The ideological discourse delineated in the political speeches of Ramiz Alia and other leading members of the Party emphasised a recognition of Albania's changing external and internal conditions. Behind the veneer of ideological correctness and rhetorical exhortations to base "scientific work on revolutionary theory and on the correct line of the Party" (Alia 1986: 21), the regime recognised and promoted specialisation and the expertise of cultural producers. Economists, physicists, mathematicians, and social scientists were asked to provide recommendations and solutions to the pressing problems facing the regime. In consequence, the sharp distinction between

\footnotetext{
${ }^{11}$ National State Archives of Albania, Academy of Sciences fonds, file 14/1982, p. 13: "Programmei i punës për zbërthimin e vendimeve të kongresit të VIII të PPSH” [Working Programme on the Analysis of the PLA's 8th Congress Resolutions].

${ }_{12}$ National State Archives of Albania, Academy of Sciences fonds, file 14/1982, p. 24: "Programi i punës për zbërthimin e vendimeve të kongresit të VIII të PPSH" [Working Programme on the Analysis of the PLA's 8th Congress Resolutions].
} 
the Party bureaucracy and "unreformed" society was overcome and social research was no longer the prerogative of any socialist citizen.

During this stage, more and more members of the cultural intelligentsia were recruited to the state bureaucracy and non-party positions. In 1990 , in a speech on the democratisation of social life, Ramiz Alia informed the members of the Central Committee that "in the apparatus of the central departments and institutions, the communists make up only $33 \%$ of the total number of employees and functionaries, while $67 \%$ of them are not party members" (1990: 4). This process, which had evolved over time, happened prior to the regime change in 1991. The official discourse during the late 1980s specified the increasing role of cultural capital and the authority of the cultural producers. The existing practice of ideological work was considered by Party ideologues such as Foto Çami to be inefficient and burdened with empty slogans and clichés (1986: 36). What was required was "more knowledge, more facts, and arguments" (ibid.). The lofty ideological and political battles were replaced by concrete social issues (Alia 1986: 12). The state socialist regime accepted the necessity of recognising the changing role and importance of cultural producers, as part of the socialist intelligentsia. "Currently, society needs people who are quite able professionally and passionate about their expertise, as well as competent in their field" (Alia 1986: 27). As Starova and Fuga (2001: 14) explain, the regime allowed a small number of ties with the Western social sciences, through the ordering of books and publications from the West or "revisionist" East, as an investment in the improvement of the ideological elite. Facing complex problems, the state socialist regime made clear that it was not succumbing to bureaucratisation and that it was not relinquishing the Party's monopoly on power. Nonetheless, the state socialist regime was no longer as monolithic after the reconfiguration of the field of power. Professors of political economy and leading planners at the State Planning Office presented new economic measures or policies to increase the efficiency of economic production and to provide more relative autonomy to state enterprises by decentralising decision-making. The First Secretary of the PLA made a strong statement: "The Party cannot interfere in the economy" (Alia 1990: 17). In the cultural and educational sector, Party directives and partinost, and the primacy of Marxist-Leninist ideology, were sidelined by the new ideological intelligentsia leading the process of making the cultural field autonomous from the political power. 


\section{The Autonomisation of the Cultural Field}

The Academy of Sciences, as the leading institution in the cultural and scientific sector, had established the institutional structure for the recruitment and education of new members of the group of cultural producers in the late 1970s. Despite initial instances of friction over their different understandings of expertise between members of the cultural intelligentsia and members of the Party-state in official meetings, Marxist-Leninist ideology was not questioned, replaced, or challenged. In the mid-1980s, the national ideology appeared less effective in legitimating the state socialist regime. The social problems to be solved increased. A few members of the cultural intelligentsia became involved in providing novel ideological propositions to overcome the waning effect of the militant and dogmatic use of propaganda. In this paper, this group of cultural producers is called the ideological intelligentsia. Not dependent on the strict Party line and correct repetition of the official Marxist ideology, and not being either Marxist sociologists or proponents of market socialism, the ideological intelligentsia articulated the crisis of legitimation through Marxist ideology. A process of differentiation between the strata of the cultural intelligentsia started to take shape. Hamit Beqja, a professor at the State University of Tirana, was one of the main proponents of policy changes in the education sector and also of more openness to progressive science. Most of his contributions were presented in official newspaper articles during the years 1987 to 1988. Aiming to curtail the effects of self-reliance or isolation in the educational system he proposed "[...] not isolating ourselves from the achievements of contemporary culture, science, and technology" (Beqja 1982: 39) as well as the "modernisation of the whole teaching and educational process at school" (ibid.).

The criticism levied at the cultural intelligentsia for relying on unreflective and uncritical use of Marxist ideology is an indication of differences among the cultural intelligentsia. Some groups or members of this stratum possessed more symbolic capital, through having articulated novel strategies of problem-solving that were recognised by the state socialist regime. Beqja presents the inefficacy of most of the cultural intelligentsia in the ideological sector in this way: "Aware of their own mediocrity, they intend to hide their lack of competence with political capital, with their family biography and their long contribution [to the socialist regime...] becoming as such a hindrance to the progress of the country" (Beqja 1989: 310). What was demanded was a more critical stance, more intellectual in- 
novation, and less and less dogmatism. On the other hand, it should be noted that this group of cultural producers supported the "progressive and democratic processes that were triggered by the Party" (Beqja 1989: 547) and not political pluralism. Interestingly enough, in his public statements in Zëri i Popullit [The Voice of the People], the official press of the PLA, Beqja enumerates the social problems facing Albanian youth, such as social deviance and extravagant personality affirmation (1989: 308), and the indolence of the workers (1989: 310). Together with Tefik Çaushi, Kristaq Angjeli, and Alfred Uçi, Beqja became a supporter of the emergence of sociology as separate from histomat.

\section{From the Sociology of Social Problems to Early Institutionalisation}

As mentioned above, in Albania in the period from 1986 to 1989 sociology was not institutionalised as a separate autonomous discipline in the universities. The first Albanian sociological association was established in April 1990 and in 1991 the Faculty of Sociology and Philosophy was established at the University of Tirana. Nonetheless, the establishment of the Sociological Association and the Faculty of Sociology and Philosophy can be traced to the cultural producers' relative autonomy from the political powers and dislocation from the interstitial position between the field of power and the cultural field. The discipline of sociology was institutionalised after 1990. Means was found, between the education sector of the Central Committee Apparatus of the PLA and the Faculty of Law and Political Sciences, to allow the establishment of a special course in the discipline of sociology in 1986 (Weinstein et al. 2011: 34). Those who were involved in this endeavour were professors of philosophy at the University of Tirana, or those who had moved from the V.I. Lenin Party School to the University of Tirana, such as Servet Pëllumbi, who co-taught a special course with Fatos Tarifa, a young scholar at that time. ${ }^{13}$

The group of cultural producers involved could be categorised in two separate, yet complementary, sub-groups. One sub-group included members of the ideological intelligentsia, such as Hamit Beqja, who started to discuss the constraints of historical materialism, and the second sub-group included those cultural producers who conceived sociological research pri-

${ }^{13}$ Other prominent members of the emerging sociological community were faculty members and the first generation of students: Artan Fuga, Lekë Sokoli, Fatmir Zani, Kosta Bajraba, Elira Çela, Zyhdi Dervishi, Klarita Gërxhani, and Teuta Starova. 
marily as the sociology of social problems, in order to provide solutions to concrete problems facing the state socialist regime. These later contributed to doing "sociology for sociology's sake." Both groups were supportive of the process of "democratisation" initiated by the regime. When the 1992 elections were won by the opposition, led by the Democratic Party, the ascendancy of the Socialist Party of Albania (ex-PLA) was ended, and the centre-right considered that a break with the past had occurred. The initial institutionalisation of sociology as a discipline, which had happened through the establishment of the Faculty of Sociology and Philosophy in 1991, was henceforth challenged by the new powers in the name of reforms. The functioning of the Faculty was suspended (Tarifa 1996).

None of those who had contributed to the emergence of sociological research and later to sociology's institutionalisation were sociologists. Most of them - when engaged in criticising bourgeois and revisionist sociology - had come into contact with foreign authors. The process of obtaining and cultivating the dispositions of the sociological habitus involved cultivating personal contacts between Albanian cultural producers and foreign sociologists who visited socialist Albania (Weinstein et al. 2011: 34). Through exchanges of letters, autodidactic learning, and the ordering of books from their foreign colleagues, the Albanian cultural producers created a community of sociologists. Yet one cannot speak of professionalised sociologists at that juncture. The affinity between the public sociology of C.W. Mills (Tarifa 2014) and the kind of sociological research done from 1986 to 1990 was determined by the structural position of Albanian social researchers as part of the field of power, due to the appreciation of cultural capital, and as proponents of applicative social research aiding the solution of concrete social problems. Being a public intellectual and a sociologist appeared not to be a contradiction to this generation of cultural producers (Tarifa 2014). The cultural products of sociologists-in-the-making included scholarly articles introducing particular sociological methods (Tarifa 1986), mostly applicative social research on youth culture, and life-style sociology (Tarifa \& Bajraba 1988; Tarifa \& Çela 1989). The position-takings of these particular members of the cultural intelligentsia did not resemble speculative theorising based on the sophisticated regurgitation of Marxist ideology or the Party's theoretical thinking. However, the cultural products that appeared between 1986 and 1990 are ambiguous, due to their structural position at the intersection of fields, and in the sense of ascribing the correct behaviour of the socialist intelligentsia vis-à-vis the regime and of contradicting the dogmatic representation of socialist reality through their con- 
crete empirical research. "In the cities, especially among the intelligentsia [...] we observe sometimes the propensity to remain within the boundaries of family life, to construct a comfortable life, and avoid social activism on the work front" (Tarifa \& Çela 1989: 63). One of the contradictions that appeared due to empirical research was related to the assumed emancipation of women. In fact, the active participation of women in political and social life was in contradiction with their low emancipation in family life (Tarifa \& Bajraba 1988: 121).

In 1989, and especially in the spring of 1990 with the creation of a sociological association, members of the sociological community had taken steps that completed the autonomisation of the scientific field, as a subfield of the cultural field. However, it should be noted that the association comprised sociologists in the making as well as members of the creative intelligentsia, who henceforth became a community of public intellectuals. This happened prior to regime change in December 1990, and before the establishment of the first opposition party, the Democratic Party, which was based on the convergence of a faction of the cultural intelligentsia opposing the regime and the students of the University of Tirana. The social activism of the sociologist or social scientist in providing pragmatic answers to complex problems was considered insufficient to complete the scientific training of new social researchers, who should be involved in proper academic practice: "[postgraduate studies] should include a number of scientific works, scientific papers, conference papers, etc. [...]" (Dervishi 1988: 52). The first scientific conferences - and the only ones in the late 1980s - on sociological topics were organised by the Scientific Sector of Philosophy on the "Sociological Overview of Our Spiritual Life" and the "Philosophical and Sociological Overview of Empirical Reality" in October 1989 and November 1990 respectively (Weinstein et al. 2011: 36-37). At this time, some sociologists started to distance themselves from the party bureaucracy and even to face issues of censorship with regard to their empirical research. The removal of secrecy from official state statistics, and the constraining effect of "ideological vigilance," were pertinent concerns of social scientists (Tarifa 1990: 98).

\section{/// Conclusion}

This paper has argued that the emergence of sociology in state socialist Albania can be explained by constructing a theoretical model that takes into consideration the stage theory of the evolution of the state socialist 
regime, its different modes of legitimation, and the increasing role of the cultural intelligentsia at certain critical junctures. The institutionalisation of sociology as a discipline under a state socialist regime did not occur in Albania as in most of the East-Central European countries. In most of these countries, sociologists were aiming to consolidate and institutionalise the sociological discipline, and their trajectory is rather different from the trajectory and structured position of the cultural producers in the Albanian case, who became involved in the endeavour to conduct piecemeal social research and simultaneously to enhance the legitimation of the state socialist regime.

This paper has aimed to contribute to specifying a causal mechanism linking the relaxed cultural policy of the state socialist regime with the early institutionalisation of sociology. Apart from the theoretical and conceptual tools that delineate transformations at the regime level, the Bourdieusian framework has been utilised to make sense of the autonomisation of the cultural field as a first step to emancipation from political power. On the other hand, the theoretical model has revealed the interstitial position or the ambiguity of cultural producers as part of the cultural intelligentsia in the late 1980s in socialist Albania.

Viewing the emergence of sociology in Albania in terms of the strategies of specific historical agents in establishing sociological research under the cultural policy of late socialism overturns the normative and to some extent, non-empirically validated idea about sociologists bifurcating into either accomplices of the regime or scholars censored by the regime's totalitarian nature.

Bibliography:

/// Alia R. 1969. “Të Ngrejmë në një Shkallë më të Lartë Punën Ideologjike të Partisë,” [in:] Disa Probleme të Studimeve Shoqërore, Instituti i Studimeve Marksiste Leniniste, 8 Nëntori, pp. 3-21.

/// Alia R. 1986. “Të Ngremë më Lart Punën Ideologjike të Partisë dhe Frymën e Militantizmit Revolucionar," Studime Politike-Shoqërore, vol. 11, pp. 7-29.

/// Alia R. 1990. Democratization of the Socio-Economic Life Strengthens the Thinking and Actions of the People, 8 Nëntori. 
/// Avdia B. 1969. "Rreth Përdorimit të Disa Metodave në Studimet Shoqërore," [in:] Disa Probleme të Studimeve Shoqërore, Instituti i Studimeve Marksiste Leniniste, 8 Nëntori, pp. 172-185.

/// Beliaev E., Burtorin P. 1982. "The Institutionalization of Soviet Sociology: Its Social and Political Context," Social Forces, vol. 61, pp. 418-435.

/// Beqja H. 1982. "The Progress of Culture and the General Progress of the Nation," Albania Today, vol. 62, pp. 34-39.

/// Beqja H. 1989. Rrjedhave të Sociologjisë së Edukatës e të Kulturës, 8 Nëntori.

/// Bosomitu Ş. 2017. "Sociology in Communist Romania: An Institutional and Biographical Overview," Studia UBB Sociologica, vol. 62, pp. 65-84.

/// Biberaj E. 1998. Albania in Transition: The Rocky Road to Democracy, Westview Press.

/// Bourdieu P. 1992. Rules of Art: Genesis and Structure of the Literary Field, Stanford University Press.

/// Çami F. 1972. "The Working Class and its World Historic Mission," Albania Today, vol. 3, pp. 2-17.

/// Çami F. 1986. “Të Mbajmë Lart Frymën Militante, të Zhvillojmë Mendimin Krijues," Studime Politiko-Shoqërore, vol. 11, pp. 30-37.

/// Dervishi Z. 1988. "Specializimi dhe Kualifikimi Pasuniversitar Rrisin Aftësinw e Kuadrove për Zgjidhjen e Problemeve," Rruga e Partisë, vol. 35, pp. $48-54$.

/// Hoxha N. 1969. "Studimet Shoqërore - Mjet i Rëndësishëm për Ngritjen në një Shkallë më të Lartë Shkencore të Punës Drejtuese të Organizatave të Partisë dhe për Edukimin Revolucionar të Punonjësve," [in:] Disa Probleme të Studimeve Shoqërore, Instituti i Studimeve Marksiste Leniniste, 8 Nëntori, pp. 22-49.

/// Jowitt K. 1992. The New World Disorder: The Leninist Extinction, University of California Press.

/// Konrád G., Szelényi I. 1979. The Intellectuals on the Road to Class Power, Harvester Press.

/// Kostallari A. 1969. "Mbi Shtrirjen e Shtresëzimin e së Drejtës Kanunore në Shqipëri dhe mbi disa Çështje që Lidhen me Studimin e saj e me Orga- 
nizimin e Luftës kundër Mbeturinave të së Vjetrës," [in:] Disa Probleme të Studimeve Shoqërore, Instituti i Studimeve Marksiste Leniniste, 8 Nëntori, pp. $120-131$.

/// Lalaj A. 2015. Pranvera e Rrrejshme e Pesëdhjetëg jashtës: Vështrim Studimor mbi Konferencën e Tiranës dhe Dokumente për Protagonistët e saj, Infbotues.

/// Lane D. 1970. "Ideology and Sociology in the U.S.S.R," The British Journal of Sociology, vol. 21(1), pp. 43-51.

/// Larrabee S.F. 1978. "Wither Albania?," World Today, vol. 34, pp. 61-69.

/// Mara H. 1969. "Mbi disa Cështje të Zhvillimit të Forcave Prodhuese dhe të Përsosjes së Marrdhënieve në Prodhim në Proçesin e Ndërtimit të Plotë të Socializmit," [in:] Disa Probleme të Studimeve Shoqërore, Instituti i Studimeve Marksiste Leniniste, 8 Nëntori, pp. 102-109.

/// Omari L. 1972. "The Dictatorship of the Proletariat and the Fight against Bureaucracy," Albania Today, vol. 12, pp. 18-22.

/// Rigby T.H. 1982. "Political Legitimacy, Weber and Communist Monoorganizational Systems," [in:] Political Legitimation in Communist States, eds. T.H. Rigby, F. Ferenc, Palgrave Macmillan, pp. 1-27.

/// Rouček S.J. 1958. "The Sovietization of Albanian Education," The Slavic and East European Journal, vol. 2, pp. 55-60.

/// Shalin D.N. 1978. "The Development of Soviet Sociology, 1956-1976," Annual Review of Sociology, vol. 4, pp. 171-191.

/// Starova T., Fuga A. 2001. "Social Sciences in Albania," [in:] Social Sciences in Southeastern Europe, eds. N. Genov, U. Becker, International Social Science Council, pp. 13-34.

/// Sulstarova E. 2007. Arratisja nga Lindja: Orientalizmi Shqiptar nga Naimi te Kadareja, Botimet Dudaj.

/// Szacki J. 1998. "Polish Sociology 1940-1989: In Service of Society or in Service of the Regime?," Polish Sociological Review, vol. 122, pp. 115-131.

/// Szelényi I. 1982. "The Intelligentsia in the Class Structure of the StateSocialist Societies," American Journal of Sociology, vol. 88, pp. S287-S326.

/// Szelényi I., Martin B. 1988. “The Three Waves of New Class Theories," Theory and Society, vol. 17, pp. 645-667. 
/// Tarifa F. 1986. "Metoda e Anketimit në Studimin e Dukurive Shoqërore," Kultura Popullore, vol. 13, pp. 91-106.

/// Tarifa F. 1990. Në Kërkim të Faktit Sociologjïk, 8 Nëntori.

/// Tarifa F. 1996. "Neither Bourgeois nor Communist Science: Sociology in Communist and Post-Communist Albania," Communist and Post-Communist Studies, vol. 29, pp. 103-113.

/// Tarifa F. 2014. Imagjinata Sociologjike dhe Bota jonë Sociale, Onufri.

/// Tarifa F., Bajraba, K. 1988. "Vështrim Sociologjik mbi Kohën e Lirë të Punonjësve,” Studime Politike Shoqërore, vol. 11, pp. 116-138.

/// Tarifa F., Çela E. 1989. "Mënyra e Jetesës. Fushë e Gjerë Veprimtarie për Afirmimin e të Resë,” Rruga e Partisë, vol. 36, pp. 59-65.

/// Tarifa F., Sokoli L. 2006. Mendimi Sociolog jik Shqiptar, Rinia.

/// Verdery K. 1991. National Ideology under Socialism: Identity and Cultural Politics in Ceausescu's Romania, University of California Press.

/// Voříšek M. 2008. "Antagonist, Type, or Deviation? A Comparative View on Sociology in Post-War Soviet Europe," Revue d'Histoire des Sciences Humaines, vol. 18, pp. 85-113.

/// Waters M. 1989. "Collegiality, Bureaucratization, and Professionalization: A Weberian Analysis," American Journal of Sociology, vol. 95, pp. 945972.

/// Weinstein J., Shatro B., Mile K. 2011. Sociologjia Shqiptare dhe Profili i Studuesit Fatos Tarifa : Festschrift, Ombra GVG.

/// Wright O.E. 1974. "To Control or to Smash Bureaucracy: Weber and Lenin on Politics, the State and Bureaucracy", Berkeley Journal of Sociology, vol. 19, pp. 69-108.

/// Xholi Z. 1984. "Popular Socialist Republic of Albania - A State of the Dictatorship of the Proletariat," Albania Today, vol. 75, pp. 14-18.

/// Ypi L. 2007. "The Albanian Renaissance in Political Thought: Between the Enlightenment and Romanticism," East European Politics and Societies, vol. 21, pp. 661-680. 
Archival materials:

/// National State Archives of Albania, Academy of Sciences fonds, file 19/1979: "Tematika për fushat e shkallës së pare të kualifikimit shkencor pasuniversitar në shkencat shoqërore" [Topics for the First Level of Postgraduate Scientific Qualifications in Social Sciences].

/// National State Archives of Albania, Academy of Sciences fonds, file 14/1982: "Programi i punës për zbërthimin e vendimeve të kongresit të VIII të PPSH" [Working Programme on the Analysis of the PLA's 8th Congress Resolutions].

/// National State Archives of Albania, Council of Ministers fonds, file 47/1979: "Relacion për forcimin e partishmërisë proletare dhe të karakterit kombëtar të studimeve në institucionet e shkencave shoqërore dhe në shkollat e larta" [Report on Strengthening the Proletarian Partinost and the National Character of Studies in Institutions of Social Sciences and of Higher Education].

/// National State Archives of Albania, Council of Ministers fonds, file 47/1979: "Projektvendim për forcimin e mëtejshëm të partishmërisë proletare dhe të karakterit kombëtar të studimeve në shkencat tona shoqërore" [Draft Law to Further Strengthening the Partinost and the National Character of Our Social Studies].

/// National State Archives of Albania, Council of Ministers fonds, file 47/1979: "Procesverbal i mbledhjes së kryesisë së këshillit të ministrave mbi shqyrtimin e relacioneve" [Council of Ministers Meeting Record on Examining Reports].

/// National State Archives of Albania, Council of Ministers fonds, file 47/1979: "Procesverbal i mbledhjes së kryesisë së këshillit të ministrave mbi shqyrtimin e relacioneve" [Council of Ministers Meeting Record on Examining Reports]. 


\section{/// Abstract}

This paper addresses the following research question: what shaped the emergence of sociological research during the period of late socialism in Albania? The second aim of the paper is to reveal the causal mechanism by which a liberalised cultural policy brought about a shift. The traditional role of the socialist intelligentsia lessened in importance while the role of social scientists emerged. In the very final years of the state socialist regime, in 1989 to 1990, these latter were pitted against Party cadres and representatives in defending a limited yet free academic practice. In order to explain the intricate, early process of the emergence of sociology under state socialism in Albania, this paper utilises a layered theoretical framework that tries to capture the interaction between stages of regime development, the coexistence of various competing modes of legitimation, and the transformation of the heteronomous sector of cultural production into an emergent field of cultural production.

Key words:

autonomisation of the cultural field, cultural producers, field of power, sociology, state socialism

/// Sokol Lleshi - Ph.D. graduate in political science from Central European University, Budapest. Since October 2016, he has been working as a lecturer in political science at the Department of Applied Social Sciences at the European University of Tirana. His main research interest is the intersection of regime-formation strategies during transitions from authoritarian rule and political projects of breaking with the past in post-socialist Eastern Europe. Other research interests are the effect of societal contestation and politicisation on processes of institutional emergence, the sociology of intellectuals, and the political economy of development.

Email:sokol.lleshi@uet.edu.al 
/// Teuta Starova - has a Ph.D. from the University of Tirana. She was part of the emerging sociological community in the late 1980s at the University of Tirana. She holds the position of senior lecturer in the Department of Sociology of the University of Tirana. Her main research interests are political sociology in developing countries and the role of democracy in transition economies. Other research interests include voting behaviour in post-communist countries, the social effects of public policies, democratisation, and social movements.

Email: teutastarova@unitir.edu.al 